Faculty of Business

Faculty Publications

This is a post-print version of the following article:

History and the micro-foundations of dynamic capabilities, Strategic Management Journal

Roy Suddaby, Diego Coraiola, Charles Harvey, and William Foster 2019

The final publication is available at:

https://doi.org/10.1002/smj.3058

Citation for this paper:

Suddaby, R., Coraiola, D., Harvey, C., \& Foster, W. (2019). History and the microfoundations of dynamic capabilities. Strategic Management Journal, 41(3), 530556. https://doi.org/10.1002/smj.3058 


\title{
History and the Micro-foundations of Dynamic Capabilities
}

\author{
Roy Suddaby \\ University of Victoria \\ \& \\ Liverpool University \\ Diego Coraiola \\ University of Alberta \\ Charles Harvey \\ Newcastle University \\ William Foster \\ University of Alberta
}

Primary contact author:

\author{
Roy Suddaby \\ Peter B. Gustavson School of Business \\ University of Victoria \\ Business \& Economics Building Room 254, 3800 \\ Finnerty Rd, Victoria, BC V8P 5C2 \\ rsuddaby@uvictoria.ca
}




\begin{abstract}
Research Summary: The capacity to manage history is an important but undertheorized component of dynamic capabilities. We argue that the capacity to manage the interpretation of the past, in the present for the future, is a critical ability that informs a firm's ability to successfully enact changes needed to adapt to disruptive technology. We identify and elaborate three specific cognitive interpretations of history - history as objective fact, history as interpretive rhetoric and history as imaginative future-perfect thinking - and demonstrate how these different views of history can be mobilized by managers to sense, seize and reconfigure around opportunities made available by understanding the invisible thread of technology.

Managerial Summary: History is typically understood to be a constraint on a manager's ability to effect change. A firm's past is assumed to create inertia in routines and structures that compromise a firm's ability to change. We show how acquiring a broader understanding of the role of history can improve a manager's ability to enact organizational change. Studying the evolution of technology over time and across products allows managers to sense opportunities created by technological change. Using different narrations of the past as continuous or disruptive can improve a manager's ability to motivate or resist change. Using the past to construct convincing scenarios of the future, managers can enrol key stakeholders in the industry to support a strategic direction that advances the firm's strategic goals.
\end{abstract}




\section{Introduction}

History has played an important role in the development of strategic management theory. In some cases, the role of history is explicit - strategy and structure (Chandler, 1962), path dependence (Arthur, 1994), and technological lock-in (David, 1985). In other cases - geographic clusters (Porter, 1998), the resource based view (Barney, 1991) - history is implicit. In both uses, however, history is seen to be exogenous to the firm and, therefore, beyond managerial control.

Some theorists, however, see history as an endogenous resource of the firm. Long standing institutions such as the British monarchy (Hobsbawm \& Ranger, 1983), the nation-state (Anderson, 1983; Duara, 1985), and the church (Koselleck, 2004), are seen to endure through their ability to construct powerful historical narratives that create identity, and facilitate or inhibit change. Institutions persist by perceiving history as an endogenous and manageable resource.

Practitioners have begun to elaborate precisely how history can be managed. A growing number of specialized consulting firms - the Winthrop Group, The History Factory, History Associates - offer "heritage management" services for large corporations. Firm history, they argue, can be crafted to create brand identity, retain employees, or motivate change. A growing list of practitioner publications detail precisely how history can be managed (Smith \& Steadman, 1982; Mooney, 1986; Roowan, 2009; Seaman \& Smith, 2012; Lasewicz, 2015; Weindruch, 2016). Rather than viewing history as a variable beyond managerial control, these academics and practitioners see history as a core managerial competence.

We adopt this view here. Our thesis is that the capacity to manage perceptions of the past, in the present, for the future, is a critical cognitive capacity that underpins the micro-foundation of any dynamic capability. Most theory in strategic management is premised on the assumption that the firm's ability to adapt to a distant and highly uncertain future environment is based on 
resources acquired in the past and deployed in the present. The notion of dynamic capabilities, however, introduces an important degree of temporal agency in which some firms sense future opportunities, seize them in the present, and reconfigure the firm by decoupling it from burdensome routines and practices from the past. We build on Teece's (2007) articulation of dynamic capabilities by theorizing how firms use the past, not only to anticipate change in the future and adapt accordingly, but to actively manage perceptions of the past to enact compatible futures. Managers acquire a degree of agency by adopting a view of history as an enabler rather than an impediment to change (Suddaby, Foster \& Quinn-Trank, 2010; Suddaby \& Foster, 2017).

\section{Dynamic Capabilities and History}

There are competing versions of the concept of dynamic capabilities (Peteraf, Stefano \& Verona, 2013) that diverge, largely, on the question of whether dynamic capabilities can explain strategic adaptation of the firm in rapidly changing environments. Teece and colleagues (Teece, Pisano \& Shuen, 1997; Teece, 2007) answer 'yes' to this question and observe that the construct applies to firm adaptation under conditions of rapid environmental change, typically initiated by technological innovation. Eisenhardt and Martin (2000), by contrast, argue the opposite - i.e. that dynamic capabilities can explain firm adaptation in relatively stable environments but cannot explain adaptation in high velocity environments. We adopt the Teece perspective in our analysis. We are most interested in how perceptions of history can be used to facilitate organizational adaptation in conditions of profound and disruptive technological change.

The important but largely implicit role of history in the concept of dynamic capabilities is perhaps best captured by Teece's (2007: 1320) observation that the long run performance of a firm “is determined by how the (external) business environment rewards its heritage". Teece's (2007) articulation of the "micro-foundations" of dynamic capabilities offers a useful extension of the role 
of history in the theory of dynamic capabilities. In Teece's view, history is a perception of a firm's ability to respond to future challenges based on an evaluation of its history of adaptation. A foundational component of dynamic capabilities is the ability to overcome cognitive limitations and framing biases that arise from historically embedded experiences. Teece (2007) identifies three cognitive meta-capabilities; the ability to sense and shape opportunities and threats, the ability to seize those opportunities, and the ability to reconfigure assets and structures in order to maintain competitiveness.

In reviewing the literature on dynamic capabilities, we observe three different views of history - as a fixed asset or resource, as a process of embedding capabilities in routines, and as a perception created by managing collective cognitions about the past and its relationship to an imagined future. This somewhat contradictory use of history raises serious questions about the role of history in processes of organizational change. Is history an objective and immutable property that constrains an organization's ability to adapt? Does history remove managerial agency? Or, alternatively, is history a symbolic resource that provides agency in a manager's ability to interpret and narrate a version of history consistent with the strategic goals of the firm? As we argue here, it is entirely plausible that all three views of history - as objective fact, interpretive process and imaginary perception - may be accurate and true managerial agency is derived from the ability to fluidly think in all three modes of historical reasoning simultaneously.

\section{Historical Consciousness: History as a Strategic Resource}

History, as a discipline, is fragmented by the same epistemological debates present in other social sciences. The varieties of history that emerge from these debates reflect a continuum characterized by three views of history; positivist (history as fact), interpretivist (history as storytelling) and phenomenological (history as sensemaking). While the positivist view of history 
as an objective science has been the dominant perspective, increasingly, critics have come to challenge this view as inaccurate and naïve (Carr, 1961). Some question historians' claim to objectivity (Novick, 1988; Veyne, 1984). Others argue for more interpretivist (Zerubavel, 2003) and phenomenological (Eliade, 1963) views of history.

It is, of course, entirely possible that all three interpretations of history can usefully coexist. The ability to simultaneously embrace all three perspectives of history as viable options for understanding the relationship between the past, present and future gives managers a "historical consciousness" (Suddaby, 2016) or a degree of reflexivity about history as an endogenous symbolic resource of the firm. Such reflexivity reasserts managerial agency over the past because the capacity to manage the objective, interpretive and imaginative elements of history is a critical cognitive capacity that underpins the micro-foundations of dynamic capabilities.

The most common view of history in management is as an objective phenomenon that constrain the ability of a firm to change. Constraints occur as a result of three major influences of the past. First, the founding conditions of an organization imprint values, routines and processes on a firm that persist long after the founder and that make innovation difficult (Stinchcombe, 1965). Second, as organizations age, routines, practices and traditions tend to create cognitive (Oliver, 1997), structural (Hannan \& Freeman, 1984) and institutional (Selznick, 1949) resistance to change. Finally, the historical cumulation of past decisions tend to delimit future decisions, as captured by such concepts as path dependence (Schreyögg \& Sydow, 2011), historical or technological lock-in (Arthur, 1994) or escalation of commitment (Staw, 1976). In this view, history is seen as an exogenous constraint on the ability of a manager to change the organization.

An interpretive view of history focuses less on the immutable events of the past, and more on how those historical events are interpreted. In this view, managerial agency arises from how 
the past is narrated in the present, assuming thereby that the act of narration is highly agentic. The term rhetorical history is applied to describe the "strategic use of the past as a persuasive strategy to manage key stakeholders of the firm" (Suddaby, Foster \& Quinn-Trank, 2010: 157).

The agency of managers in their interpretation of the past arises, primarily, from three key practices. First, historians use periodization strategies to impose thematic assumptions of continuity or disruption on the flow of historical experience. By bracketing temporal experience into periods of continuity or discontinuity, managers can exert agency over the burden of the objective past by declaring a new era in which traditional practices no longer apply (Ybema, 2014). Second, managers use memorialization practices to signal an affinity with past practices, and therefore create a sense of continuity in an organization, or to indicate a discontinuity with the past (Dacin, Munir \& Tracey, 2010; Bell \& Taylor, 2016). Finally, firms engage in rhetorical practices of strategic forgetting through which they remove the constraints of objective history by selectively erasing the elements of the organizational memory that resist change (de Holan \& Phillips, 2004).

Scholars have also begun see history less as a forensic exercise of reconstructing the objective past, and more as a way of using the past to legitimate an imagined future (White, 1973; Veyne, 1984; Kosseleck, 1985). Management scholars working in this vein see history as a mode of sensemaking that can be used to motivate change through the use of future-perfect-thinking (Beckert, 2013; Weick, 1995). Because change occurs in an uncertain future, and because sensemaking occurs in a somewhat obscure past, managers can mobilize change by envisioning a particular future as having already occurred, structuring narratives of the past to offer a coherent and plausible way forward (Gioia, Corley \& Fabbri, 2002).

Each of these uses of history - objective, interpretive and imaginative - reinforce the three micro-foundations of dynamic capabilities (Teece, 2007). We propose that historical reasoning in 
its objective, interpretive and imaginative forms respectively are fundamental to the processes of sensing opportunities, seizing opportunities, and reconfiguring products, firms and markets (See Figure 1). This means that strategic managers equipped with the requisite historical cognitive competencies - objective-empirical, interpretive-rhetorical and imaginative-future perfect thinking - are better able than managers without these competencies to engage effectively in processes or organizational renewal and development.

\section{INSERT FIGURE 1 ABOUT HERE}

In what follows we elaborate our thesis that the capacity to manage perceptions of history is a cognitive skill that underpins the micro-foundations of dynamic capabilities. We demonstrate how a firm's capacity to manage objective history contributes to a firm's capacity for sensing opportunity. We demonstrate how a firm's capacity to manage interpretive history can lead to an enhanced capacity to seize opportunity. Finally, we demonstrate how a firm's capacity to manage imaginative history can lead to an enhanced capacity to reconfigure products, firms and markets.

\section{The Role of Objective History in Sensing Opportunity}

"What Descartes did was a good step. You have added much several ways, and especially in taking the colours of thin plates into philosophical consideration. If I have seen a little further it is by standing on the shoulders of Giants." Sir Isaac Newton, letter to his rival, Robert Hooke

Newton's famous quote stands for the somewhat obvious notion that discovery rarely occurs in isolation. Any innovation has a history and, when examined closely, what may appear to the untrained eye as a disruptive technology, can often be seen as a series of micro-innovations that evolve over time. Schumpeter's (1942) observation that innovations arise as new combinations of old knowledge, reinforces what historians of technology have long understood, that new technological regimes tend to arise out of old ones (van den Ende \& Kemp, 1999). 
Technological innovations are typically connected by an invisible thread of incremental discoveries that occur slowly over time and which diffuse broadly across products and industries. A powerful illustration of this is offered by Bernstein's (2002) detailed historical analysis of the evolution of mechanisms of feedback-control. Bernstein describes the incremental shift of five modes of feedback technology - the escapement (clocks), the governor (mechanical engines), the alleron (planes), the gyro (ships, planes, missiles) and the amplifier (telephone) - over centuries.

Not only do each of these different product lines share a similar "grammar" (Hard \& Knie, 1999) of the logic of mechanical governance, the technology used in each product line shares a long history of incremental innovation. The escapement, for example, is a device that draws on Galileo's early understanding of measuring time with a pendulum, and which offers a means of correcting the inevitable loss of momentum of the pendulum over time by using an 'escape wheel'. The logic and design of the escape wheel was introduced in the early 1700s by John Harrison, and can be traced longitudinally from early mechanical clocks to the digital watch. Technology, thus, has an invisible thread of historical continuity that can be traced across time.

Bernstein suggests that, because the thread of innovation is so incremental, we often can only make sense of the continuity by looking backward. Identifying where the thread will lead requires decision-makers to adopt a cognitive capacity for understanding the grammar of technology. The cognitive skills required to anticipate technological change are based on the ability to use objective history to overcome the cognitive constraints of taken-for-granted assumptions that frame new technology in the assumptions of old technology (DiMaggio, 1997). As Rosenberg (1994: 24) observes "in early years, railroads were though of merely as feeders into the existing canal system...the radio was thought...to have potential applications mainly where wire communication was impractical, for example, ships at sea and remote mountain locations". 
In part, the cognitive blind spots triggered by new technology are driven by the fact that, because they are based on micro-innovation, early forms of a new technology are often not obviously superior to old ones. Early mechanical clocks, for example, were massive, expensive and not nearly as reliable as the old technology (Bernstein, 2002). Similarly, because technologies are usually applied to very specific purposes by experts narrowly trained in refining those applications, it is very difficult for individuals close to a particular technology to fully appreciate the extent and variety of potential applications. To fully anticipate the path of innovation, managers must acquire the ability to cognitively extend the innovation into the future by extrapolating the grammar of technology into a broader understanding of its social, political and economic potential.

The form of history most appropriate for sensing the latent opportunities presented by early forms of innovation is objective history. Viewed objectively, history is simply data - a collection of facts about the past. This is the scientific view of history skilfully applied by Chandler (1962) to discern the evolving relationship between organizational strategy and structure in an emerging new organizational form. It is an approach to history premised on a logic of sequential and patterned causality between events and informs many of the core concepts of strategic management. The implicit model of history in such concepts as imprinting, path dependence and structural inertia, is one in which events tend to occur in somewhat predictable patterns. Continuities and discontinuities can be anticipated by a careful examination of objective historical data. In the context of technology, the invisible thread of historical innovation that Bernstein describes can be identified by a detailed and comprehensive examination of innovation in a product line in order to discover the underlying logic or grammar of technology.

The ability to sense opportunities by analyzing objective data goes beyond typical organizational memory systems (Walsh \& Ungson, 1991) or performance data (Ansoff, 1980). 
Instead, it requires managers to acquire longer cognitive horizons that focus on the microtransitions within a technological trajectory that share a common technological logic. Microtransitions in technology are identified by paying attention to "micro-historical" data (Akgit \& Nichols, 2018). Managers must acquire a high degree of historical depth and breadth in a given technology in order to grasp its underlying grammar. More critically, a truly objective historical analysis is more than merely tracing the technical line of innovation. It also requires the ability to think in a temporally contextualized manner (Gadamer, 1981; Weinberg, 1985), with sensitivity to the political, social and economic contexts within which micro-innovations take root and others do not. This fine-grained, temporally sensitive understanding of objective history, thus, enhances a manager's ability to sense opportunity by capturing subtle shifts in the grammar of a technology.

\section{Proposition 1: Objective historical reasoning enhances a manager's ability to sense opportunities created by latent changes in technology}

Sensing latent change in the invisible thread of technology requires decision makers to develop distinct forms of cognition that improve management's capacity for historical reasoning. Historical reasoning refers to critical thinking skills in which managers, informed largely by primary sources, construct meaningful accounts of the past (Neustadt \& May, 1985). It is a form of cognition that sensitizes both the attention (Joseph \& Wilson, 2017) and perception (Helfat \& Peteraf, 2015) of decision makers to two types of cognition that are useful in improving the ability of managers to sense latent change in the technological environment. First, managers must acquire longer mnemonic frames by adopting diachronic forms of historical reasoning. Second, managers must acquire broader mnemonic frames through the use of synchronic historical reasoning.

Diachronic Historical Reasoning: Diachronic reasoning is a form of cognition required to understand change over time (Montangaro \& Pownell, 1996). Historical diachronic reasoning is the ability of managers to detect the common thread of micro-innovations that connect products in 
a given technological regime. Historical diachronic thinking requires a sensitivity to long-run historical data. Managers tend to be more sensitive to threats than opportunities because they tend to privilege short-term solutions (Jackson \& Dutton, 1988). However, by acquiring a historian's diachronic mindset - i.e. an attentiveness to long-run patterns of incremental, co-evolutionary change in technology - managers are more likely to see emergent opportunities than threats.

Perhaps the best example of historical diachronic thinking is illustrated by Ada Lovelace's capacity to connect the old technology of textile manufacturing to the emergent technology of computers. The invention of the Jacquard weaving machine in 1801, which used a primitive form of punch cards to create patterns in textiles, inspired Charles Babbage in the application of punch cards in his Analytical Engine, the precursor of the modern computer. Babbage's financial supporter Ada Lovelace observed "the Analytical Engine weaves algebraic patterns just as the Jacquard loom weaves flowers and leaves" (Marculescu et al, 2003: 1995).

Historical diachronic reasoning can also help decision makers understand how technology can succeed or fail because of the cultural-historical context in which it emerges. Attending to the micro-historical conditions within which an innovation occurs requires a high sensitivity to the intimate relationship between technology and culture. Historians, thus, describe the unique German character of the diesel engine (Hard \& Knie, 1999) which could only succeed in a culture that valued high quality engineering in Germany over manufacturing efficiency, which was more valued in the US (Hard \& Knie, 1999). A similar observation is made about differences in the refridgeration technology in Germany and the US (Dienel, 1995). Diachronic thinking, thus, makes a manager sensitive to how the cultural conditions of technology change over time.

\section{Proposition 1A: Diachronic historical reasoning enhances a manager's ability to sense opportunities created by latent changes in technology}


Synchronic Historical Thinking: The ability to trace the invisible thread of microinnovations that connect technologies across time can also be used to trace the diffusion of products across space. Innovations are not confined to a single product or market, but typically move fluidly across multiple products and markets. As Bernstein (2002) demonstrates, the basic logic of feedback control technology was not confined to a single machine, but progressed from clocks to airplanes to communication devices. The capacity to anticipate the diffusion of an emerging technology in the present, thus, requires a detailed understanding of its history. Synchronic reasoning makes sense of a technological innovation by locating it in a wider network of innovations that draw from a common historical thread of related innovations.

Synchronic reasoning is premised on research that questions the myth of the sole genius inventor. Artistic, cultural or technological innovations rarely emerge from a single inventor. Rather, they arise from a social network or community of individuals engaged in a common project (Becker, 2008). This is why inventions tend to occur simultaneously by different inventors:

"Edison didn't invent the lightbulb; he found a bamboo filter that worked better as a filament in the lightbulb developed by Sawyer and Mann, who in turn built on lighting work done by others. Bell filed for his telephone patent on the very same day as an independent inventor, Elisha Gray; the case ultimately went to the US Supreme Court...The Wright Brothers were the first to fly at Kitty Hawk as a result of an improvement they made to a basic wing structure designed by others" (Lemley, 2012: 71011)

Many breakthrough inventions are the result of temporally related clusters of innovation.

The capacity of decision makers to sense opportunity by using objective history can be improved by extending the breadth of their historical knowledge beyond the boundaries of the firm or the industry within which the firm is positioned to include historical data that embraces the broader mnemonic community of innovation. The weakness of most organizational memory systems is that they are highly introspective. They tend to focus almost exclusively on the history 
of the firm itself and, thus, ignore the broad-based historical trends that might reveal the traces of incremental innovation that cumulate into technological regime shifts. The firm thus becomes blind to the broader technological landscape from which micro-innovation emerges.

To address this problem, some firms restructure their organizational archives to embrace a broader mnemonic community. Forbes and Kirsch (2011) document how some firms combine archives at the product or industry level. Such broad-based forms of collective memory offer several advantages over traditional corporate archives. Foremost, industry level archives collate data from competitors, making it easier to analyze the history of innovation that results from competition. Combined archives also include institutional level data that tracks the regulatory behavior of government, trade associations, standards organizations and other actors who shape the entire ecosystem of innovation. Collective archives often include records of failed firms and products, which helps overcome the success bias that plagues most management research.

By expanding the breadth of historical data beyond the firm, managers acquire an enhanced capacity for synchronic historical reasoning. The ability to trace a thread of innovation across product and market boundaries improves the ability to anticipate both new applications for existing products, and threats that emerge from outside a competitive group. It is the opaqueness of the grammar of technology, however, that makes it difficult for managers to sense both the threats and opportunities that arise when one technological regime evolves into another.

This was the failure of major technology firms like IBM and HP that did not recognize the opportunity presented by the personal computer (PC), which became possible with Intel's creation of the micro-processer in the 1970s. When Steve Wozniak, co-founder of Apple, presented his plans for a personal computer to his bosses at HP, the idea was dismissed as "a toy" (Moritz, 1984). The failure of IBM and HP, was not their inability to see the future evolution of the market for 
PCs, but rather was a failure to see the PC as simply another stage in the thread of innovation from mainframe computer to desktop and, ultimately, to the cellphone (Langlois,1992).

Proposition 1B: Synchronic historical reasoning enhances the ability of managers to sense
opportunities created by the diffusion of technology across products and markets

Both synchronic and diachronic historical reasoning rely on the ability of managers to think analogically. A common misassumption is that studying history is useful simply because it allows managers to avoid the mistakes of the past. This is the application of traditional scientific method - i.e. deductive reasoning - to history, which erroneously assumes that patterns of historical events are repeated through time. Historians, however, understand that no set of historical circumstances are ever entirely identical. Rather, there is a general pattern that may be carried from one time to another. As Mark Twain is purported to have said, history doesn't repeat itself, but it does rhyme.

In order to detect the 'rhyme' of objective history, managers must be adept at analogical reasoning in which the similarities and differences between events are compared to determine if a deeper, meta-similarity exists between them (Cohen, 2005; Neustadt \& May, 1985). Analogical reasoning can help managers deconstruct the overwhelming detail of both the historical depth of diachronic micro-innovation and the historical breadth of synchronic micro-diffusion of innovations and can, ultimately, reveal the invisible thread that connects seeming different products. Analogical reasoning is a form of historical thinking that allows firms like to engage in "technology brokering" or repurposing innovations across industries and products (Hargadon \& Sutton, 2002). Acquiring synchronic, diachronic and analogical cognition is premised on the ability to use objective history in sensing opportunity.

\section{Using Rhetorical History to Seize Opportunity}

"The garage is a bit of a myth. We did no designs there, no breadboarding, no prototyping, no planning of products. We did no manufacturing there." Steve Wozniak, co-founder of Apple 
The idea that technology entrepreneurs start out in a humble garage is one of the enduring origin myths of Silicon Valley. The myth has a basis in objective history - Hewlett Packard (HP) was founded in a garage at 367 Addison Avenue and its first product was created there in 1939. Still, following the logic of the invisible thread of micro-innovations in technology, the true origins of HP "can be traced back to Hewlett's Master's thesis at Stanford University, where he enjoyed access to cutting-edge technology, fellow enthusiasts and the guidance of legendary electrical engineer Fred Terman, one of the entrepreneurs' lecturers" (Gann \& Dodgon, 2016). The myth of the start-up garage, however, is so compelling a story to aspiring entrepreneurs, investors and the general public, that, as Steve Wozniak's quote indicates, subsequent tech entrepreneurs feel compelled to recreate the tradition, more out of the intent to appear legitimate than actual need. The start-up garage is an invented tradition (Hobsbawm \& Ranger, 1983), a highly stylized version of a past that has value, not in its empirical accuracy, but in its power to mobilize resources.

The start-up garage is also an example of rhetorical history, a highly stylized use of the past to legitimate action in the present (Suddaby et al, 2010). History is an act of narration, a form of storytelling, sometimes comprised of "verbal fictions, the contents of which are as much invented as found" (White, 1973: 82). Research in rhetorical history follows this intellectual tradition by analyzing contexts in which the narration of history can be seen as an act of creative reconstruction of the past by powerful interests in organizations used to frame and motivate action (Suddaby \& Greenwood, 2005; Dialpez \& Stifano, 2018), to foster identification and purpose by internal stakeholders (Ravasi, Rindova \& Stigliani, 2019) and to strengthen relationships with external stakeholders by convincing them that, because they share a common past, they also share a united future (Suddaby \& Foster, 2017; Boje, Haley \& Saylors, 2016). Collectively, these studies show that the capacity to re-interpret the past makes it less determinative and thus less agentic. 
The ability to use history to manage change is an important element of the microfoundation of the capacity to seize opportunity. Seizing opportunity rests largely on the ability of the firm to motivate organizational change while maintaining the commitment of key stakeholders. When a new technological or market opportunity is identified, the firm must mobilize significant financial and human resources in order to take advantage of the sensed opportunity. Accomplishing this requires the firm to overcome the structural inertia of highly embedded routines, the path dependence of prior resource commitments, and the historical imprinting of past strategic initiatives that committed the firm to a business model now under threat by an emergent technology or an evolving structural shift in market competition.

In order to overcome these inertial tendencies, the firm must use the past to overcome resistance to change. New "insights and markets - particularly those that challenge conventional wisdom - will likely encounter negative responses. The promotors/visionaries must somehow defeat the naysayers, transform internal views and facilitate necessary investment" (Teece, 2007: 1327). The ability to overcome resistance to change and seize opportunity requires managers to reduce the fear of change by convincing resistors that the proposed change is neither as profound or as risky as they originally thought. This difficult task of persuasion is accomplished by rhetorical history - a re-framing of the past in a narrative structure that serves strategic interests.

When change is latent - i.e. occurs so incrementally that it is difficult for actors embedded in the present to discern - decision makers must frame history in a way that convinces key stakeholders that a particular sequence of long-run events of incremental change does, in fact, constitute a fundamental inflection in the evolution of a market or a technology. This also requires considerable interpretive and rhetorical skill on the part of key decision makers in the firm, who must construct a compelling interpretation of history that convincingly demonstrates a shift from 
one epochal period to another. In such cases, managers must become historiographers - literally, those who write stories about the past (Maclean, Harvey, Sillince \& Golant, 2018).

\section{Proposition 2: Rhetorical history enhances the ability of managers to seize opportunities by using stories of the past to mobilize the resources necessary to motivate change.}

Three strategies of rhetorical history are used to allow firms to overcome the naysayers and seize opportunity. First, the past must be reinterpreted to maintain organizational or product identity in the face of profound change. Organizational stakeholders must be convinced that seizing the opportunity is consistent with the firm's past. Innovation is presented within a narrative of tradition. Second, the past must be reinterpreted in order to motivate naysayers to embrace change. Sometimes this can be accomplished by convincing stakeholders that the firm has a history of innovation and risk taking. More typically, however, it requires management to convince the organizational stakeholders of the historic significance of the threat to the firm if it fails to adopt the proposed change. Finally, and perhaps most critically, rhetorical history is used to patch over the inevitable contradictions and conflicts that occur between promoters of change, on one hand, and naysayers, on the other. We elaborate each of these in the balance of this section.

Framing Change as Continuity: A key rhetorical strategy for overcoming resistance to change is to manage the perceptions as to whether a course of action represents change or continuity. Events can often be framed to suggest that what might appear as a substantial breach with the past is, in fact, a logical extension of the firm's core identity. Considerable empirical research has demonstrated how the interpretation of an entity's history can be skilfully reconstructed to support the argument that "we have always done it this way". Often, the ability to rhetorically reconstruct change as continuity is premised on a discourse of identity.

Social historians observe how history can be reconstructed to create a false sense of coherence and continuity in social institutions. The term "invented tradition" captures the 
observation that many traditions commonly understood to be long-standing institutions are, in fact, of relatively recent origin, invented to create a false sense of continuity in identity (Hobsbawm \& Ranger, 1983). Thus the 'tradition' of Highland clans has been shown to a strategic invention designed to promote Scottish independence (Pittock, 1991; Trevor-Roper, 1983). In fact, most nation states are constructed on the basis of invented histories designed to create a sense of a common historical ethnicity and a shared future destiny (Anderson, 1983). The official history of Iceland, for example, has been shown to minimize the role of early Irish explorers and privilege Norwegian settlers in an effort to preserve Iceland's ethnic identity as Scandinavian (Jones, 1986).

Studies have shown how organizations promote change by restructuring them as expressions of a continuous identity. Suddaby and Greenwood (2005), for example, describe how the accounting profession promoted the historical narrative "we have always been multidisciplinary" to justify the adoption of a new organizational form that combined law and accounting in a single firm. Schultz and Hernes (2013) describe how executives at the Danish toy giant LEGO carefully reconstituted a range of different forms of history, including archival texts, artefacts and oral memory, in order to characterize a massive strategic reorientation in the company as a form of historical continuity. LEGO was not changing, they argued, but rather was simply getting back to its historical roots and organizational identity as a toy company.

The success of this rhetorical strategy is based on the ability of a firms' interpreted history to create a bond of identification between employees and the firm. By managing employees' positive memories of the firm, commitment to the firm can trump any degree of organizational upheaval. Sometimes the sense of mnemonic identification with the firm is so strong amongst employees that their commitment to the organization as a mnemonic community will persist even after the demise of the firm. This was the observation of Walsh and Glynn (2008) in their case 
study of Digital Equipment Corporation (DEC). Even though DEC had vanished through a series of corporate mergers, the firm was kept alive "in the collective memory and activities of former DEC members through alumni associations, online message boards, newsletters and publications ... that preserve[d] valued aspects of DEC identity" (Walsh \& Glynn, 2008: 262).

Collectively, these studies demonstrate that firms can enhance change by reframing disruptive change as a continuous extension of an invented past. When done successfully, the perceived trauma and risk of change is supplanted by a perception that the proposed change is actually less traumatic and risky because the firm has done this before, it is part of the historical legacy of the firm, and that the proposed change is really a return to the firm's founding values and skills. A coherent and powerful historical identity provides firm managers with powerful rhetorical material through which profound change can be reconstructed as continuity.

Proposition 2A: Rhetorical history facilitates a firms' ability to adapt by framing the perception of change as continuity

Motivating Change as a Moment of History: In some cases, a firm can only mobilize a commitment to seize opportunity by exaggerating, rather than minimizing, perceptions of change. In such cases the change must be framed as a significant breach with the past, an inflection-point in time of momentous historic significance. In such cases, history must be used to create a sense of potential catharsis in the face of adversity. A critical element in motivating a successful company to move beyond a crisis in the present, Weindruch (2016) argues, is to construct a narrative that demonstrates the importance of the decision for the future of the entity. Stakeholders must be convinced that they are facing an historic choice that threatens the entity's viability. Managers must characterize the importance of the choice by provocative language - terms like "progressive," "pioneering," "state-of-the-art", "first" - to underscore the choice facing stakeholders as a "crossing the Rubicon" moment of history (Arndt \& Bigelow, 2000). 
The term "invented transitions" - a turn of phrase that cleverly adapts the Hobsbawm and Ranger (1983) term "invented traditions - is used to describe the use of rhetorical history to motivate change (Ybema, 2014). Rather than suggesting that traditions are invented to mask change as continuity, rhetorical history is often used "not to restore or reaffirm continuity, commonality, commitment and identity, but instead to gain support for change and to counter competing views by dislodging the past and creating a sense of discontinuity" (Ybema, 2014: 496). Ybema describes how editors at the Dutch newspaper de Volkskrant selectively drew on instances of the firm's storied past that promoted a narrative of change in editorial orientation from a Catholic labour-oriented paper to a progressive and professionally independent journal.

Collectively these studies demonstrate how the rhetoric of historical discontinuity is used to motivate change. In order to seize opportunity, key decision makers convince stakeholders of an impending historical discontinuity, a breach with the past, that connotes a sense of urgency and a need to change. The creation of epochs, eras and periods, is an effort to impose historical significance on events in one segment of time that distinguishes them from others is a common historical technique of periodization - creating a perception of discontinuity in the past by emphasizing change in a single variable of interest in order to exaggerate the sense of change. The danger, of course, is that periodization can be used in both objective and self-interested ways.

Perhaps the best illustration of the misuse of periodization is offered by Lepore's (2014) critique of the expansive use of the term "disruptive change". Lepore criticizes the increasing use of the "disruptive technology" (Christensen) or "technological discontinuities" (Foster, 1986) in both academic and popular literature to suggest that the risks of change today are somehow more profound than in the past. Empirical evidence, however, does not support this argument. Data drawn from multiple comprehensive datasets suggests that "the rate of business startups and the 
pace of employment dynamism in the US economy has fallen in recent decades and that this downward trend accelerated after 2000" (Decker, Haltiwanger, Jarmin \& Miranda, 2014: 3). The study also shows that the average age of businesses is increasing, and fast growth industries are on the wane. What is increasing, Lepore (2014) and others (Fox, 2014) conclude, is the rhetoric used to create the perception that we are in an era of unmitigated change.

In assuming a historical consciousness, an important part of a manager's cognitive skill is the ability to use history to motivate change. A critical part of this is the ability to help the organization break the shackles of historical inertia and commit to change. This can be achieved through the rhetorical capacity to convince key stakeholders of the need for change - by constructing a compelling narrative of how the pace of change of the current era is significantly different from the past, and the dangers that wait in the absence of change. The ability to use history to mask continuity as change is a critical managerial skill that allows firms to seize opportunity.

\section{Proposition 2B: Rhetorical history facilitates a firms' ability to adapt by framing the perception of continuity as change}

Repairing Contradictions: Inevitably, firms that rhetorically reinterpret their past in order to facilitate change create contradictions that must be managed. When change is masked as continuity or identity is reconstructed into somewhat arbitrary periods, stakeholders can often be left confused by what the true character of the firm or product actually is or whether a new strategic commitment constitutes a breach with the past or the rediscovery of a latent but enduring historical path. Making sense of these contradictions requires a high degree of cognitive complexity (Smith \& Tushman, 2005) managed at the collective level of the firm.

These contradictions are also managed by the skilful use of rhetorical history. Just as historical events can be constructed as stable or novel, continuous or changing, so too can those events be rhetorically reconstructed as having occurred or not. Organizational forgetting, thus, is 
the key rhetorical strategy through which firms use history to repair contradictions. Organizational forgetting refers to the loss of organizational knowledge that occurs through benign neglect (de Holan \& Phillips, 2004), a form of natural entropy that is presented as a counterpoint to the concept of organizational learning. More interesting for our purposes, however, is the less examined phenomenon of deliberate organizational forgetting - i.e. those instances where forgetting is intentional because it serves a larger strategic purpose. This form of forgetting helps to manage contradictions by selectively erasing inconvenient facts of the past that no longer serve a strategic purpose and through which awkward contradictions arise. An excellent example of strategic forgetting is offered by Linde's (2009) ethnographic analysis of change in a Midwestern insurance company that was struggling to maintain its traditional culture of collegiality and rich professional relationships with clients after a strategic reorientation that moved the firm from a history of collective (shared-pool earnings) to a competitive (eat-what-you-kill) compensation culture. The firm was struggling to maintain coherence between its collegial past of shared resources and its current manifestation as an internally competitive and externally aggressive sales firm.

As the company faced a growing range of economic pressures externally and cultural pressures internally, it resolved the problem, Linde (2009) observes by "working the past" or selectively reconstructing its historical identity to erase the collegial elements of the past that conflicted with the desired competitive culture of the present firm. Managers justified this erasure by using the threat of the "dead hand of the past" as a motivation for continually innovating both the culture of the organization and its understanding of the historical origins of the culture. Linde shows how even the oral history of the firm, as reflected in watercooler conversations and informal socialization practices, gradually assigned the contradictory elements of the firm's history to the category of "peripheral" elements of the firm's history before they were ultimately forgotten. 
A broad range of related studies reinforce the importance of systematic and strategic organizational forgetting in overcoming the contradictions created by using revisionist history to motivate change. Anteby and Molnar (2012) point to systematic forgetting in assisting an aeronautics firm that was struggling to preserve a coherent identity as a French organization in spite of its long history of support by, and alliance with, American interests. The firm's official history strategically omitted potentially contradictory elements of the firms' past that made reference to the American influence in an effort to present a coherent and unified history of French innovation. Ravasi and Phillips (2011: 127) similarly, demonstrate how the Danish technology company Bang \& Olufsen used a strategy of “identity drift”, or the selective narration of the firm's history to produce a "gradual identity change, characterized by increasing misalignment between past claims and beliefs embodied in official identity statements and changing manager's beliefs manifested in new strategic investments."

\section{Proposition 2C: Rhetorical history facilitates a firms' ability to adapt by managing collective forgetting}

Ultimately a firm's ability to seize opportunities is predicated upon its ability to motivate an organizational commitment to change. As we show above, the ability to reframe the past is a critical skill in managing change. By framing change as continuity, elevating the historical significance of events and by smoothing over the inevitable contradictions generated by selective forgetting, managers can strategically facilitate change in order to seize opportunity.

\section{Using Imaginative History to Reconfigure Products, Firms and Markets}

"The best way to predict the future is to invent it" Alan Kay, $\mathrm{PhD}$, pioneer of object-oriented programming and graphical user interface

An entirely different view of history occurs when the past is used to legitimate an imagined future. This use of history requires a form of managerial cognition termed pluperfect reasoning 
defined as "thinking in the future perfect tense" (Weick, 1969: 66). Future perfect thinking is a form of prospective sensemaking in which resources are mobilized and collective action is motivated by an imagined future state of the world. Actors are motivated, in part, by the degree to which they believe in the imagined future and the causal path to achieve it (Beckert, 2013). The credibility of any such imagined future, in turn, rests upon the degree to which the proposed "future present" is legitimated in a coherent account of the past (Kosseleck, 1988). The ability to engage in pluperfect reasoning is a critical form of cognition for anticipating and adapting to technological change because, "a technology is not merely a system of machines with certain functions; rather it is an expression of a social world" (Nye, 2004: 171). A coherent future, thus, motivates and a plausible past legitimates social action.

The power of a coherent and credible imagined future is in its ability to generate multilevel institutional change. We understand, through prior research, that many innovations fail, not because of their technical superiority, but rather because they lack the support of peripheral technology and collaborative social institutions (Nelson, 1994). The strategy of technological lockin is founded on the awareness that new products or technologies are deeply embedded in, and coevolve with, a wide range of social, political and economic institutions. Effective strategic change, thus, can never be restricted to a single product or firm, but must necessarily mobilize corresponding change in the networks, markets and institutions within which the product or firm is embedded. While most research describes the incredible restrictive effect of this state of historical lock in (Leibowitz \& Margolis, 1995), Kay's quote captures the essence of a path forward. By creating a clear and compelling imaginary future, and positioning your innovation in it, entrepreneurs can successfully escape the restrictive burden of history. Future perfect reasoning is a fundamental cognitive skill in reconfiguring products, firms and markets. 
Future perfect reasoning relies on the power of using history to generate a coherent vision of the future. All enduring institutions understood the persuasive power of using the past to control narrations of the future (Orwell, 1949) and, as a result, have exercised strict control over who should be allowed to predict the future. Kosseleck (1985: 13) reminds us that the Catholic Church sentenced Joan of Arc to death because of her visions of the future; and a "ruling principle [Herrschaftsprinzip] of the Roman Church was that all visionaries be brought under control". Kings and Queens of England and France, similarly, closely policed the ability to predict the future and disobedient prophets were commonly jailed or killed.

Medieval churches and nation-states controlled their prophets because they understood the transformative power of future perfect reasoning. So too do modern corporations like Google, IBM and Ford, all of which employ futurists (O'Neil, 2017) because they understand that the ability to articulate a coherent view of the future based on an interpretation of the past can be a formidable tool for legitimating change. A central premise of modern scenario planning is that we study the past not only to understand how it might constrain future options, but also to understand how the past can be used to "co-construct memories about the future" (Larsen \& Willert, 2018: 1). In contrast to the prior assumptions of history as objective fact or interpretive skill, future perfect reasoning values history for its imaginative capacity and assumes that the past can be used to construct plausible and desired futures that enhance the ability of the firm to generate new products, reinvent their organizations and reconfigure markets. As such, the ability to reconstruct the past in order to articulate a desired utopian future is a critical skill in overcoming historical lock-in and mobilizing embedded change.

Teece (2007) observes that the capacity to reconfigure is a critical micro-foundation of a firm's ability to exploit opportunities. Reconfiguration occurs at three levels of analysis, at the 
product level, the organizational level and at the level of the competitive market. In order to fully engage in product innovation, a firm must have the capacity to integrate knowledge from a broad variety of sources - both inside and outside the organization. Such "distributed" models of product innovation permit the firm to reach out "beyond its own boundaries to access and integrate technology" (Teece, 2007: 1337). This approach to product innovation requires the firm to develop a degree of reflexivity - i.e. to overcome the cognitive limitations and biases that arise from long standing commitments to prior technologies or "established assets". Put another way, in order to innovate new products and technologies for the future, the firm must overcome taken-for-granted modes of thinking established in the past and so deeply embedded in existing routines that firms may be largely unaware of them or how they constrain innovation. The reflexivity needed to overcome this embedded agency is achieved through the use of imaginative history.

A second key element of the micro-foundation of reconfiguration is the ability to "cospecialize" at the organizational level as a result of a new product innovation. The need to cospecialize arises from the observation that a new technology or business model cannot be incorporated into an organization without first adapting a broad array of interlocked activities that will be affected by introducing the new product or practice. Relatedly, the full capacity of the new technology will not be realized without the creation of new complementary products or the evolutionary expansion of those products. So, for example, new software products are often limited by the slow evolution of memory capacity in micro-processers or hardware restrictions in computers. In order to exploit the new technology, the firm must often reconfigure the ecology of complementary routines, processes and technologies within the firm that complement and support the new innovation. As we demonstrate below, the ability to reconfigure organizational structures 
that permit the co-specialization of activities needed to support an innovation requires a coherent vision of the product and its impact on the firm, a vision dependent upon future perfect thinking.

Finally, Teece (2007) argues that reconfiguring also occurs at the level of the market or industry. In order to fully exploit an innovation, enterprises must have the ability to "shape their ecosystem" by using their investment choices and other decisions to "...set technological and market trajectories, particularly early on in the development of a market (Teece, 2007: 1341). Innovations are sometimes so profound that a firm must sometimes adopt the role of an institutional entrepreneur - actors who have the resources required to change existing institutional arrangements or introduce new ones in order to serve self-interest (Greenwood \& Suddaby, 2006). So, for example, Rao (1994) describes how the leading automobile manufacturers employed a range of institutional strategies between 1895 and 1912 to reconfigure the transportation infrastructure in the US in order to facilitate the mass market adoption of auto transport. To do so, the automakers had to articulate a clear and convincing vision of a utopian future in which major metropolitan centres in the US were connected by paved highways and the economic benefits that would accrue as a result of the legitimation of a superior form of transportation.

\section{Proposition 3: Imaginative history enhances the ability to reconfigure markets by engaging in future perfect thinking.}

Collectively, Teece (2007) identifies three key components of reconfiguration; the ability to reconfigure existing knowledge in order to innovate products, the need to reconfigure firms in order to integrate those products into existing routines, and the need to reconfigure markets in order to create the ancillary infrastructure needed for the new products to successfully supplant existing ones. The three components reflect a cascading ecosystem in which reconfiguration at the higher level of analysis cannot occur without a corresponding reconfiguration at lower levels of analysis. The three components reflect three distinct uses of imaginative history and future perfect 
thinking designed to assist in product innovation, organizational change, and institutional reconfiguration.

Imaginative History and Product Reconfiguration: Innovations rarely occur in a void. Rather, new products result from incremental accretions as one idea evolves into another. The history of this evolution can sometimes enable a dramatic shift from one technological form to another. We noted previously the historical continuity between the textile and computer industries, both of which share the grammar of punch-card technology (Park, Mackenzie \& Jayaraman, 2002). More commonly, the historical grammar of a technology can be traced to multiple threads that combine to create a new product, market or industry. Such was the case in the invention of television, which as Winston (1998: 91) describes, resulted from the combination of seven different technological threads that had been in existence for decades:

"Phosphors were understood. Fluorescent paint was being manufactured. The longdistance electrical transmission of images by means of the facsimile telegraph had been a reality since the middle of the nineteenth century. The cathode ray tube existed. Research into electro-optical effects led, by 1905, to the direct modulation of an electric arc through the action of a light beam and in 1907 the emission of light from a crystal rectifier had been reported (Phillips 1980:207). Knowledge of thermionic amplification had produced, by 1907, the practical basis for radio and radio-telephony systems. Photoelectric effects had been utilised in the production of light-sensitive cells by 1913."

By the beginning of the First World War, Winston observes, the "dream of television was over thirty years old." The threads were united by a Punch cartoon artist who sketched an image of a device in which two people could talk on a screen connected by a telephone. Television, thus, was the product of an imaginative unification of long-standing technological grammars.

On occasion, the historical grammar of a technology may not be useful in producing the innovating new product itself, but may be useful in convincing consumers to adopt the new product. Edison, for example, embedded the design features of old technology - the flame of the 
old kerosene lamps - in the design of the light bulb in order to alleviate the concern of homeowners wary of the risk of having electricity course through their homes. The flame shape of the first bulbs are skeumorphs - symbolic referents embedded in new products to reassure users by reminding them of the historical continuity between the old and the new (Hargadon \& Douglas, 2001).

More typically however entrepreneurial firms familiar with the historical grammar of a technology can use that knowledge to identify new uses for old products. In their ethnography of the iconic product design firm IDEO, Hargadon and Sutton (1997) describe how much of the firm's success in innovation is the result of the firm's routinized capacity to study old innovations and update them for new purposes. IDEO self identifies as a "technology broker" that creates new technology by moving it through space (from one client to another) and time (from old applications to new). Both practices require the firm to be skilled in the use of imaginative history. The firm's success is an extension of the understanding that much of product innovation is based upon having a deep knowledge of the historical grammar of the technology and extrapolating or extending that knowledge from past to future applications.

\section{Proposition 3A: Imaginative history enhances the ability of key decision makers to acquire a future perfect understanding of the grammar of the technology .}

Imaginative History and Organizational Reconfiguration: Imaginative history can be used to apply future perfect thinking to the challenging task of reconfiguring an entire organization as a result of new product innovations. Biggart (1977) offers a profound example of this in the massive restructuring of the US Postal Service in order to accommodate new automation technology in letter and package delivery. A key tool used by management to assist in the change project was to reinvent the inhouse employee magazine Postal Life, which was originally an "innocuous compendium of human interest stories and bits of information about postal history" 
(Biggart, 1977: 420), as a platform for communicating a utopian vision of the firm's future. After the reorganization, the magazine became:

"an important medium for disseminating management's point of view on automation, labor negotiations, work conditions, and other issues of importance to management-union relations. It also served as a way of breaking down the former ways of thinking of employees used to the previous ideology and non-competitive posture of the POD" (Biggart, 1977: 420)

Executives adapted an instrument traditionally used to communicate the past to key stakeholders into an oracle of the future, skilfully connecting past, present and future in a single platform.

Kaplan and Orlikowski (2013) illustrate how a telecommunications firm, struggling with how to reorganize itself in order to accommodate the emergence of new fibre-optic technology, engaged in future perfect thinking. Team leaders addressed the issue by first adopting an openminded and temporally expansive form of scenario planning that the researchers describe as "temporal work". They actively engaged in debates about the interpretation of history that "linked their interpretations of the past, present, and future so as to construct a strategic account that enabled concrete strategic choice and action". Notably, these scenarios constantly iterated between socially constructed perceptions of the organization's past identity and how those interpretations could change perceptions of the degree of volatility of the external environment.

The authors conclude that the more intensely they debated these temporal linkages between past identity and future environmental scenarios "the more likely the strategies departed from the status quo". Strategic planning, thus, is less about getting the facts of the past "right" and more about negotiating different perceptions of the past and how they might allow the organization to understand future interpretations of the external environment in a more creative way. Temporal work embraces the notion, well understood by royalty and the Church, that prophesies can be selffulfilling and, because of this, the capacity to produce prophesies can and must be managed. 
Boje and colleagues (2016) examine the role of "antenarratives" in the internationalization strategy of Burger King. Antenarratives are organizational stories that "justify strategies and visions in which managers want stakeholders to believe, but that presently have no justification" (Boje et al, 2016: 394). The construct is drawn from Bakhtin's notion of chronotopes that are historically based genres of sensemaking. Through a detailed analysis of the internal archives, Boje and colleagues demonstrate the rich rhetorical resource that history provides stakeholders who are interested in resisting or legitimating change. The authors demonstrate how perceptions of Burger King's past was used to construct narratives of how the fast-food empire could be successful in the international marketplace. History was used to characterize the international environment as friendly or hostile, weak or strong, stable or dynamic - depending on the advocate's stance regarding international diversification. The dynamic capability offered by antenarratives, the authors conclude, is that dialogical views of the past can lead to imaginative and creative capabilities for organizations and how they innovate the future.

In these examples we see an emerging sensitivity to the importance of imaginative history in successfully reconfiguring organizations in order to absorb the disruptive influence of new technologies or business models. We also see a growing degree of skill in applying techniques of future perfect thinking in that process.

\section{Proposition 3B: Imaginative history enhances the ability of key decision makers to acquire a future perfect understanding of the implications of disruptive technologies and business models.}

Imaginative History and Market Reconfiguration: Innovations do not occur in a vacuum. Rather, they occur within the context of broad socio-technical systems that require the support of consumers, complementors, regulators and a host of non-market institutions (Geels, 2002). In order to successfully exploit an innovation, therefore, firms must reconfigure markets around the 
anticipated implications of their innovation (Teece, 2007). In order to accomplish this, they must engage in two related practices of imaginative history. First, they must position their innovation in the context of a convincing and coherent future - i.e. an imagined new market order in which the innovation plays a central role. Second, they must persuade the key stakeholders in the market of the plausibility of that imagined future. As we demonstrate in this section, such plausibility is typically achieved by convincingly positioning the future innovation in the legitimacy of the past.

Successful entrepreneurs, either individuals or firms, are visionaries who gain resources and access to markets by providing a coherent vision of the future. It is no accident that technological entrepreneurs are active prophets. Bill Gates (1995) authored The Road Ahead to describe his vision of the "information highway", clearly to position Microsoft as a central player in that imagined future. America Online founder Steve Case, similarly penned the Third Wave to describe his vision of the "internet of everything", a vision of emerging singularity in which much of our future life will be predicated upon human connectivity to the world wide web. Innovations succeed, in part, by entrepreneurs' ability to persuade markets of new worlds in which "future attributes are created as entrepreneurs envision new ways of using assets to produce goods and services" (Foss, Foss, Klein \& Klein, 2007). Similarly, research has shown that venture capital is more likely to flow to start-up firms that put forward a compelling account of how their product will be "contextually embedded" into a coherent future vision (Martens, Jennings \& Jennings, 2007). Meeting this standard requires a nuanced capacity to engage in future perfect thinking.

The ability of a self-interested economic actor to construct a socio-technological imaginaire is predicated on the ability of the prophet to convince stakeholders that it is a plausible future. Typically, such imagined futures are legitimated by grounding them in history. That is, stakeholders must be convinced that the "imagined new social order is understood as the natural 
result of adopting an emerging, unproven technology” (Bátiz-Lazo et al, 2014; 105). The success of the world's first multinational hotel chain, Hilton International, occurred, in part, because of Conrad Hilton's ability to position the notion of a global hotel chain within a teleological historical narrative of America's history of fighting communism (Maclean, Harvey, Suddaby \& O'Gorham, 2018). Similarly, Bátiz-Lazo and colleagues (2014) demonstrate how the international banking community, interested in the potential cost savings of moving away from cash, helped to orchestrate a global conversation about the "cashless society", an imagined future of electronic commerce. IBM CEO Thomas Watson was the key socio-technological prophet in this conversation in which he argued that the cashless society was a historical inevitability.

A key strategy used to persuade actors of the historical inevitability of a sociotechnological imaginaire is by periodization, dividing history into teleological epochs or eras that construct a plausible, though not certain, form of path dependence. AOL founder Steve Case presents a masterful example of periodization in his argument that the technological evolution of the internet is now entering a third wave. The first era, he argues, focused on building the technological infrastructure. The second era was devoted to building "on top" of this infrastructure through the creation of search engines and retail behemoths. The coming era, he suggests, is a utopian democratization of the internet in which much of human existence will be built around internet access to quotidian lifestyle functions. The persuasiveness of the argument is based on its grounding in history and the legitimacy of the author's experience in the first two eras. The elaborateness of the historical narrative and its apparent scientific precision through periodization offers a degree of practical credibility because, in part, the sweeping scope of the narrative and its elaborate detail provides a degree of practical credibility that serves to distinguish what Alfred Schütz described as “design fantasies” from “mere fantasies” (Beckert, 2013: 225). 
Markets can be also reconfigured by using future perfect thinking to reconceptualize our collective understanding of temporality and the pace of change. We somewhat unreflectively accept characterizations of modern environments as being increasingly "hypercompetitive" or "high velocity" without questioning where those characterizations come from, whether they are empirically accurate or who might benefit from them. Innovative firms can destabilize and reconfigure entire industries if they can convince key stakeholders that previously held temporal assumptions are incorrect. This was FED EX founder Fred Smith's key insight in demonstrating to the parochial and stable package delivery industry that the basis of competition could be restructured around the speed of delivery rather accuracy or reliability. Similar economic disruptions can be observed in the growing economic impact of the "slow food movement" (Pietrykowski, 2004) which offers a "socio-technological imaginaire" in which fast food chains like Burger King and McDonalds simply do not exist.

\section{Proposition 3C: Imaginative history enhances the ability of key decision makers to acquire and articulate a coherent and convincing socio-technological imaginaire.}

The capacity to reconfigure markets, thus, requires firms to imagine and communicate alternative futures as plausible (if not inevitable) extensions of the past. This is perhaps the most potent use of the past because it is predicated less on the ability of the firm to adapt to the environment and based more, instead on the capacity to persuade the environment to adapt to the firm. The ability to imagine a singular coherent future, and to structure that future in a plausible teleology of past, present and future, takes the random chaos of future uncertainty and anchors strategic decisions in the present on plausible imagined futures.

\section{Discussion}

History has been an important but undertheorized element of many important concepts in strategic management. In most of these concepts - imprinting, sunk costs, structural inertia, path 
dependence, technological lock-in - history has been presented as a deterministic pattern of events exogenous to the firm that reduces managerial agency. The concept of dynamic capabilities, by contrast, admits the possibility that some firms can escape the burden of history and engage in adaptive change. A critical insight of Teece's (2007) description of the micro-foundations of dynamic capabilities is that firms are able to overcome the constraints of the past by "unshackling the enterprise from dysfunctional processes and structures designed for an earlier period" (Teece, 2007: 1341). The precise mechanisms by which this occurs, however, remain unclear.

Our analysis addresses this question by demonstrating how adopting a broader epistemological understanding of history introduces a new cognitive understanding of the relationship between the past, present and future that enables, rather than constrains, the possibility of change. We extend Teece's (2007) framework by demonstrating how each micro-foundation is premised on a distinct view of history. Traditional assumptions about history have generated managerial cognitions that make the past appear deterministic, which in turn, creates perceptual barriers to even imagining the possibility of change.

We introduce the idea of historical consciousness which underscores the fact that in order to sense, seize and reconfigure opportunities, decision makers must adopt more reflexive set of cognitive assumptions about history and its relationship to change. We identify three specific cognitive frames of history - as objective fact, as rhetoric and as imagination - that guide decision makers in their ability to sense, seize and reconfigure opportunities and facilitate processes of strategic adaptation to technological change.

An objective view of history can be an antidote to the cognitive "sunk costs" assumption that the past constrains options in the future. As we demonstrate, few technological innovations occur ex nihilio. Rather, they emerge from an invisible thread of cumulative micro-innovations 
that can be traced diachronically, through a single innovation, and synchronically, across multiple innovations. Managers who have acquired a detailed grasp of the objective history of relevant technologies are better equipped to sense opportunities created by technology than those who have not. Thinking synchronically and diachronically requires the use of analogical thinking in time, a specific form of historical consciousness that allows managers to overcome the cognitive constraints of the past.

A rhetorical view of history provides managers who have successfully anticipated a latent trend in the evolution of technology the capacity to overcome the cognitive and emotional barriers to change that make it difficult for firms to seize opportunity. The self-reinforcing dynamics of path dependent behavior offers a degree of comfort in resisting change and creating nostalgic emotional attachments to past success that has become embedded in mythologized core values that create "core rigidities" in organizations (Miller, 1992). Overcoming these rigidities and erasing emotional barriers to change can only occur through reframing continuity as change, change as continuity and, when necessary, deliberately forgetting select events of the past. The ability to seize opportunities is predicated on the ability to skilfully interpret history and present plausible new frames of the past that will motivate key stakeholders to identify with a need to change.

The capacity to reconfigure an enterprise (or a market) in order to exploit opportunities requires an imaginative approach to history and rests on the ability of managers to think in the future perfect tense - i.e. to act as if a desired future state has been achieved and to systematically postulate the implications that might have for the firm. Prospective sensemaking rests on considerable research that shows that it is easier to write a detailed history of an imaginary event that is proposed to have already occurred than one that is presented as having occurred in the past (Bartlett, 1932; Gioia \& Thomas, 1996). The ability to generate detailed but convincingly rational 
accounts of a prospective future are critically important competencies for firms that seek to mobilize the institutional resources needed to exploit opportunity. Decision makers must generate scenarios of alternative futures and then persuade key stakeholders inside and outside the organization of their plausibility and encourage them to act "as if" the scenario has already occurred. The temporal orientation needed to support the micro-foundational capability to reconfigure is highly future-oriented, but the legitimacy of any such effort relies heavily on the ability to situate a vision of the future in the past.

The cognitive categories of objective, rhetorical and imaginative historical reasoning, are analytically, but not empirically, distinct. While separate in theory, they necessarily co-occur in practice. Each type of cognition, however, is likely to dominate during different stages of sensing, seizing and reorganizing. In empirical practice, any successful effort to reconfigure a product, organization or market by creating a vision of the future cannot be successful unless the foundation for the imagined future is premised on a rational and plausible set of objective historical facts.

This is perhaps most evident in Andy Hertzfield's term "reality distortion field" to describe Apple co-founder Steve Jobs' successful effort to reconfigure the MacIntosh and save Apple computers. Initially successful, the MacIntosh had fallen from the leading personal computer in the world because of competitors who imitated the innovative characteristics of the MacIntosh at lower price points. Jobs devised a strategy for reducing costs by shrinking twenty different product lines into four in an unrealistic time frame of ten months. He accomplished this massive reorganization through "a confounding melange of a charismatic rhetorical style, an indomitable will, and an eagerness to bend any fact to fit the purpose at hand" (Isaacson, 2011: 118). Jobs' capacity for "reality distortion" describes a co-presence of objective historical facts, a highly uncertain imagined future and a compelling description of a possible path between the two. 
Relatedly, the cognitive categories of objective, rhetorical and imaginative historical reasoning are each necessary, but in isolation, insufficient for firms to sense, seize and reconfigure around opportunities created by technological change. An example of this is offered by Polaroid, who anticipated the threat of digital photography but failed to act on it. Polaroid was an early innovator in the transition to instant photography. Based on a successful intellectual property lawsuit against Kodak, in 1986 Polaroid controlled the entire market for instant photography. Fifteen years later, however, Polaroid filed for protection from creditors.

Polaroid clearly had accumulated sufficient objective historical knowledge to capture the grammar of the technology of photography and trace its 'invisible thread' to an imagined future in which digital photography dominated. Buse (2010: 215) observes that as early as 1991, at its annual meeting, Polaroid distributed to its shareholders a document that fully described the sociological imaginaire of the future of photography:

"Beneath an image depicting a Polaroid camera, a Polaroid print, a scanner, a computer, and a laser printer, the document details how in the future 'image-dependent businesses' will rely on "converting ... images into digital data that can be easily integrated with other computer data"

Despite its obvious grasp of the objective history of its core technology, and a clear future vision of where the thread of technology would lead, Polaroid still failed. Tripsas and Gavetti (2000) attribute Polaroid's failure to inertia - an inability to alter its business model based on lowcost/high volume production and an inability to apply its extensive knowledge of digital photography to products that were inconsistent with this business model. As one Polaroid executive is reported to have said when the company balked at commercializing one specific digital innovation, "why should we accept a 38 percent margin? I can get a 70 percent margin in film?" (Chopra, 2013). Polaroid's failure was in its inability to use rhetorical history to persuade key stakeholders to adapt to a future that they, themselves had invented. 
Our analysis has largely focused at the level of the individual by describing how managers and key decision makers in the organization may adopt nuanced forms of historical cognition that underpin the ability to sense, seize and reconfigure opportunities that arise from technological change. One of the implications of this is that the capacity to think reflexively and critically about the past, present and future is an individual difference, a capacity that is heterogenous in its distribution. While there is some empirical evidence that supports this, there is equally compelling evidence that suggests that nuanced historical thinking can be improved by training (Wineberg, 1991).

Similarly, the viability of these individually located cognitive capabilities can be enhanced by the adoption of supportive strategies at the organizational level. So, for example, we have pointed to the importance of the existence of a corporate archive, and its depth and breadth of data, in supporting the capacity for objective historical cognition. Our assumption is that the types of analogical reasoning that support the use of objective history is less a trait and more a product of critical thinking that can be learned. All of these issues, however, are empirical questions that can be addressed by future research that addresses the interaction of individual differences in historical reasoning and the role of organizational structures, practices and routines in modifying them.

\section{Conclusion}

The value of the theory of micro-foundations of dynamic capabilities is based, largely, on their ability to explain how some firms are uniquely able to adapt to profound change while others are not. The intent of this paper is to extend our understanding of micro-foundations by elaborating how the capacity to change, i.e. the ability to sense, seize and reconfigure around opportunities, is, in turn, based on an expansive awareness of how key decision makers in firms understand history. Acquiring a historical consciousness, a more expansive view of history, is a critical cognitive 
capacity that enhances the ability of key decision makers to fully exploit opportunities created by technological change. By understanding history as a creative admixture of objective facts, rhetorical narration and creative imagination, managers can begin to conceptualize history not solely as an exogenous constraint on a firm's ability to change, but rather as an endogenous resource that can be managed to facilitate strategic change.

The capacity to change is critically dependent upon our cognitive assumptions about the determinism of the past. Older models of economic thinking tended to view history as an omnipotent agent in determining causal relations between actors that coalesce into coherent patterns of progress. Contemporary understandings of history, however, have rejected the assumption that history describes a degree of agency, meaning or progress that exists beyond the interactions of individuals embedded in institutions of their own making. This view rejects grand narratives of history and replaces them with a renewed interest in understanding the causality of micro-events, the variety of ways in which those micro-events can be narratively reconstructed to motivate action toward a collective future-state. Refining these relationships, empirically and theoretically, is a critical direction for future research. 
Figure 1: The Historical Micro-foundations of Dynamic Capabilities

\begin{tabular}{|c|c|c|c|}
\hline Focal Micro-Foundation & Sensing & Seizing & Reconfiguring \\
\hline Approach to History & Objective & Interpretive & Imaginative \\
\hline Historical Competence & $\begin{array}{l}\text { Empirical } \\
\text { Ability to use objective micro- } \\
\text { historical data to: } \\
\text { - Map the historical } \\
\text { evolution of markets \& } \\
\text { technologies } \\
\text { - Trace the invisible thread } \\
\text { of the grammar of } \\
\text { technology }\end{array}$ & $\begin{array}{l}\text { Rhetorical } \\
\text { Ability to use narrative history } \\
\text { to: } \\
\text { - Mobilize commitment of } \\
\text { internal and external } \\
\text { stakeholders to a shared } \\
\text { past and identification with } \\
\text { a common mnemonic } \\
\text { community }\end{array}$ & $\begin{array}{l}\text { Future Perfect Thinking } \\
\text { Ability to use imaginary } \\
\text { history to: } \\
\text { - Manage perceptions of } \\
\text { change and continuity, and } \\
\text { - Create a vision of a shared } \\
\text { utopian future }\end{array}$ \\
\hline Organizational Competence & Organizational Memory & Rhetorical History & Prospective History \\
\hline Temporal Orientation & Past & Present & Future \\
\hline
\end{tabular}




\section{References}

Anderson, B. (1983). Imagined Communities: Reflections on the Origin and Spread of Nationalism. London: Verso.

Arndt, M. \& Bigelow, B. (2000). Presenting structural innovation in an institutional environment: Hospitals use of impression management. Administrative Science Quarterly, 45(3): 494522.

Arthur, W. B. (1994). Increasing returns and path dependence in the economy. University of Michigan Press.

Anteby, M., and Molnar, V. 2012. Collective Memory Meets Organizational Identity: Remembering to Forget in a Firm's Rhetorical History. Academy of Management Journal 55 (3): 515-540.

Barney, JB. 1991. Firm resources and sustained competitive advantage. Journal of Management, 17(1): 99-120.

Bartlett, F. C. (1932). Remembering: A study in experimental and social psychology. Cambridge, England: Cambridge University Press

Bátiz-Lazo, B., Haigh, T., \& Stearns, D. L. (2014). How the future shaped the past: The case of the cashless society. Enterprise \& Society, 15(1), 103-131.

Becker, H. S. (2008). Art worlds. University of California Press.

Beckert, J. (2013). Imagined futures: Fictional expectations in the economy. Theory and Society, 42: 219-240.

Bell, E., \& Taylor, S. (2016). Vernacular mourning and corporate memorialization in framing the death of Steve Jobs. Organization, 23(1), 114-132.

Bernstein, D. S. (2002). Feedback control: an invisible thread in the history of technology. IEEE Control Systems, 22(2), 53-68.

Biggart, N. W. (1977). The creative-destructive process of organizational change: The case of the post office. Administrative Science Quarterly, 22(3): 410-426.

Boje, D.M., Haley, U.C.V. \& Saylors, R. 2016. Antenarratives of organizational change: The microstoria of Burger King's storytelling in space, time and strategic context. Human Relations, 69(2): 391-418.

Buse, P. (2010). Polariod into digital: Technology, cultural form and the social practices of snapshot photography. Journal of Media and Cultural Studies, 24(2): 215-230.

Carr, EH. 1961. What is History. Cambridge, UK: Cambridge University Press.

Case, S. 2016. The Third Wave: An entrepreneur's vision of the future. New York, NY: Simon and Schuster.

Chandler, A. 1962. Strategy and Structure: Chapters in the history of American enterprise. Boston, MA: MIT Press.

Chopra, A. 2013. How Kodak and Polaroid fell victim to the dark side of innovation. Tech News, accessed online at https://betanews.com/2013/12/12/how-kodak-and-polaroid-fell-victimto-the-dark-side-of-innovation/

Christensen, C. M. (1997). The Innovator's Dilemma: When New Technologies Cause Great Firms to Fail. Boston: Harvard Business School Press.

Cohen, E. A. (2005). The Historical Mind and Military Strategy. Orbis, 49(4), 575-588.

Dacin, M. T., Munir, K., \& Tracey, P. (2010). Formal dining at Cambridge colleges: Linking ritual performance and institutional maintenance. Academy of Management Journal, 53(6), 1393-1418. 
David, P. A. (1985). Clio and the economics of QWERTY. American Economic Review, 75 (2): 332-337.

De Holan, P. M.., \& Phillips, N. (2004). Remembrance of things past? The dynamics of organizational forgetting. Management science, 50(11), 1603-1613.

DiMaggio, P. (1997). Culture and cognition. Annual review of sociology, 23(1), 263-287.

Dienel, H.L. 1995. Ingenieure zwischen Hochshue und Industrie: Kaltetechnik in Deutschland und Amerika, 1870-1930. Gottingen: Van den Hocht and Ruprecht.

Duara, P. (1995). Rescuing History from the Nation. Chicago: University of Chicago Press.

Eisenhardt, K. M., \& Martin, J. A. 2000. Dynamic capabilities: what are they? Strategic Management Journal, 21(10-11): 1105-1121.

Eliade, M. 1963. Myth and Reality. New York: Harper and Row.

Forbes, D. P., \& Kirsch, D. A. (2011). The study of emerging industries: Recognizing and responding to some central problems. Journal of Business Venturing, 26(5), 589-602.

Foss, K., Foss, N. J., Klein, P. G., \& Klein, S. K. (2007). The entrepreneurial organization of heterogeneous capital. Journal of Management studies, 44(7), 1165-1186.

Foster, Richard. 1986. Innovation: The Attacker's Advantage. New York: Summit Books.

Foster, W. M., Suddaby, R., Minkus, A., \& Wiebe, E. 2011. History as social memory assets: The example of Tim Hortons. Management \& Organizational History, 6(1): 101-120.

Fox, J. 2014. The Disruption Myth. The Atlantic, October Issue, accessed online at https://www.theatlantic.com/magazine/archive/2014/10/the-disruption-myth/379348/

Gadamer, H. G. (1981). Reason in the Age of Science. Translated by Frederick G. Lawrence Cambridge, MA: MIT Press.

Gann, D. \& Dodgson, M. (2016). Forget the start-up garage myth. We need golden triangles and super clusters. World Economic Forum, 03 November, 2016 accessed online at https://www.weforum.org/agenda/2016/11/the-startup-garage-myth/

Gates, B. The Road Ahead. 1995. New York, NY: Penguin.

Geels, F. W. 2002. Technological transitions as evolutionary reconfiguration processes: A multilevel perspective and case study. Research Policy, 31 (8/9): 1257-1274.

Gioia, D. A., Corley, K. G., \& Fabbri, T. (2002). Revising the past (while thinking in the future perfect tense). Journal of Organizational Change Management, 15(6), 622-634.

Hannan, M. T., \& Freeman, J. (1984). Structural inertia and organizational change. American sociological review, 149-164

Hard, M. \& Knie, A. (1999). The grammar of technology: German and French diesel engineering, 1920-1940. Technology and Culture, 40(1): 26-46.

Hargadon A. B., Douglas Y. 2001 "When innovations meet institutions: Edison and the design of the electric light". Administrative Science Quarterly, 46: 476-501.

Hargadon, A., \& Sutton, R. I. (1997). Technology brokering and innovation in a product development firm. Administrative science quarterly, 716-749.

Helfat, C. E., \& Peteraf, M. A. (2015). Managerial cognitive capabilities and the microfoundations of dynamic capabilities. Strategic Management Journal, 36(6), 831-850.

Hobsbawm, E. J., \& Ranger, T. O. (1983). The Invention of tradition. Cambridge: Cambridge University Press.

Isaacson, W. 2011. Steve Jobs. New York: Simon \& Schuster.

Jones, G. 1986. The Norse Atlantic Saga. Oxford, UK: Oxford University Press.

Joseph, J. \& Wilson, A.J. (2017). The growth of the firm: An attention based view. Strategic Management Journal, 39(6): 1779-1800. 
Kaplan, S., \& Orlikowski, W. J. 2013. Temporal Work in Strategy Making. Organization Science, 24(4): 965-995.

Koselleck, R. (1985). Future Pasts: On the Semantics of Historical Time. New York: Columbia University Press.

Langlois, R. N. (1992). External economies and economic progress: The case of the microcomputer industry. Business history review, 66(1), 1-50.

Larsen, M. V., \& Willert, S. 2018. Using Management Inquiry to Co-Construct Other Memories About the Future. Journal of Management Inquiry, 27(2) 246-259.

Lasewicz, P. 2015. Forget the past? Or history matters? Selected academic perspectives on the strategic value of organizational pasts. The American Archivist, 78(1): 59-83.

Lemley, M. A. (2011). The myth of the sole inventor. Michigan Law Review 110: 709-760.

Lepore, J. 2014. The disruption machine: What the gospel of innovation got wrong. The New Yorker, June 23 issue, accessed online at https://www.newyorker.com/magazine/2014/06/23/the-disruption-machine

Linde, C. (2009). Working the past: narrative and institutional memory. Oxford: Oxford University Press.

Maclean, M., Harvey, C., Sillince, J.A.A., \& Golant, B.D. (2018). Intertextuality, rhetorical history and the uses of the past in organizational transition. Organization Studies, 39(12), 17331755.

Maclean, M., Harvey, C., Suddaby, R., \& O’Gorman, K. (2018). Political ideology and the discursive construction of the multinational hotel industry. human relations, 71(6), 766795.

Marculescu, D., Marculescu, R., Zamora, N. H., Stanley-Marbell, P., Khosla, P. K., Park, S., ... \& Kirstein, T. (2003). Electronic textiles: A platform for pervasive computing.

Proceedings of the IEEE, 91(12), 1995-2018.

Martens, M. L., Jennings, J. E., \& Jennings, P. D. (2007). Do the stories they tell get them the money they need? The role of entrepreneurial narratives in resource acquisition. Academy of Management Journal, 50(5), 1107-1132.

Miller, D. 1992. The Icarus paradox: How exceptional companies bring about their own downfall. Business Horizons, 35(1), 24-35.

Mooney, P. F. 1986. The practice of history in corporate America: Business archives in the United States. Public History: An Introduction, 427-39.

Moritz, M. 1984. The little kingdom: The private story of Apple Computer. New York: William Morris \& Co.

Neustadt, R. \& May,E. 1986. Thinking in Time: The Uses of History for Decision Makers. New York: Free Press

Novick, P. 1988. That Noble Dream: The 'objectivity' question and the American Historical Profession. Cambridge, UK: Cambridge University Press.

Nye, D.E. 2004. Technological prediction: A Promethean problem, Pp. 159-176 in Sturken, M., Thomas, D. \& Ball-Rokeach, S.J. (Eds.), Technological Visions: The hopes and fears that shape new technologies. Philadelphia: Temple University Press.

Oliver, C. 1997. Sustainable competitive advantage: combining institutional and resource-based views. Strategic management journal, 18(9), 697-713.

Orwell, G. 1949. 1984. London: Secker and Warburg. 
Park, S., Mackenzie, K., \& Jayaraman, S. 2002. The wearable motherboard: a framework for personalized mobile information processing (PMIP). In Design Automation Conference, 2002. Proceedings. 39th (pp. 170-174). IEEE.

Peteraf, M., Di Stefano, G., \& Verona, G. 2013. The elephant in the room of dynamic capabilities: Bringing two diverging conversations together. Strategic management journal, 34(12), 1389-1410.

Pietrykowski, B. 2004. You are what you eat: The social economy of the slow food movement. Review of social economy, 62(3), 307-321.

Pittock, M.G. 1991. The Invention of Scotland: The Stuart Myth and the Scottish Identity, 1638 to present. London: Routledge.

Porter, M. E. 1998. Clusters and the new economics of competition. Harvard Business Review, 76 (6): 77-90.

Rao, H. 1994. The social construction of reputation: Certification contests, legitimation, and the survival of organizations in the American automobile industry: 1895-1912. Strategic management journal, 15(S1), 29-44.

Ravasi, D. \& Phillips, N. 2011. Strategies of alignment: Organizational identity management and strategic change at Bang \& Olufsen. Strategic Organization 9(2), 103-135.

Ravasi D, Rindova VP and Stigliani I. 2019. History, material memory and the temporality of identity construction. Academy of Management Journal

(Published Online: 15 Oct 2018: https://doi.org/10.5465/amj.2016.0505)

Roowan, R. 2009. A business case for business history: How companies can profit from their past. Amsterdam: Uitgeverij Boom.

Rosenberg, N. 1994. Exploring the black box: Technology, economics, and history. Cambridge University Press.

Schultz, M., \& Hernes, T. 2013. A Temporal Perspective on Organizational Identity. Organization Science, 24(1): 1-21.

Schumpeter, J. 1942. Creative destruction. Capitalism, socialism and democracy, 825, 82-85.

Seaman, J. T. \& Smith, G.D. 2012. Your company's history as a leadership tool. Harvard Business Review, 90(12): 45-52.

Selznick, P. (1949). TVA and the Grass Roots. Berkeley, CA: University of California Press.

Smith, G. D., \& Steadman, L. E. 1982. Present value of corporate history. Harvard Business Review, 59(6), 164-173.

Smith, W. K., \& Tushman, M. L. (2005). Managing strategic contradictions: A top management model for managing innovation streams. Organization Science, 16(5), 522-536.

Staw, B. M. (1976). Knee-deep in the big muddy: A study of escalating commitment to a chosen course of action. Organizational behavior and human performance, 16(1), 27-44.

Stinchcombe, A.L. 1965. Social structure and organizations. In J.G. March (Ed.), Handbook of organizations (pp. 142-193). Chicago, IL: Rand McNally

Suddaby, R. 2016. Toward a Historical Consciousness: Following the Historic Turn in Management Thought. M@n@gement, 19(1): 46-60.

Suddaby, R., \& Foster, W. M. 2016b. Organizational Re-Membering: The use of rhetorical history to create identification. In Oxford Handbook of Organizational Identity, edited by M. Pratt, M. Schultz, B. Ashforth and D. Ravasi. Oxford: Oxford University Press.

Suddaby, R., Foster, W.M. \& Mills, A. 2013. Historical Institutionalism. Pp. $100-123$ in New Historicism in Organization Studies, M. Bucheli \& D. Wadhwani (Eds.), Oxford: OUP 
Suddaby, R., Foster, W. M., \& Trank, C. Q. 2010. Rhetorical history as a source of competitive advantage. Pp. 147-173 in J. A. C. Baum, \& J. Lampel (Eds.), Advances in Strategic Management: The Globalization of Strategy Research: Bingley: Emerald.

Suddaby, R. \& Foster, WM. 2017. History and Organizational Change. Journal of Management, 43(1): 19-38.

Suddaby, R., \& Greenwood, R. (2005). Rhetorical Strategies of Legitimacy. Administrative Science Quarterly, 50(1), 35-67.

Teece, D. J. (2000). Strategies for managing knowledge assets: the role of firm structure and industrial context. Long range planning, 33(1), 35-54.

Teece, D. J. (2007). Explicating dynamic capabilities: the nature and microfoundations of (sustainable) enterprise performance. Strategic Management Journal, 28(13), 1319-1350.

Teece, D. J., Pisano, G., \& Shuen, A. 1997. Dynamic Capabilities and Strategic Management. Strategic Management Journal, 18(7): 509-533.

Trevor-Roper, H. (1987). The invention of tradition: The ; Trevor-Roper, tradition of Scotland. In: E. J. Hobsbawm \& T. Ranger (Eds), The invention of tradition (pp. 15-42). Cambridge, UK: Cambridge University Press.

Tripsas, M. \& Gavetti, G. 2000. Capabilities, cognition and intertia: Evidence from digital imaging. Strategic Management Journal, 21(10/11): 1147-1161.

van den Ende J, Kemp R. 1999. Technological transformations in history: how the computer regime grew out of existing computing regimes. Research Policy 28(8): 833-851.

Veyne, P. 1984. Writing History. Manchester, UK: Manchester University Press.

Walsh, I. J., \& Glynn, M. A. 2008. The way we were: Legacy organizational identity and the role of leadership. Corporate Reputation Review, 11(3), 262-276.

Walsh, J. P., \& Ungson, G. R. 1991. Organizational Memory. The Academy of Management Review, 16(1): 57-91.

Weick, K. 1979. The social psychology of organizing. Reading, MA: Addison Wesley.

Weick, K. 1995. Sensemaking in organizations. Thousand Oaks, CA: Sage.

Weindruch, B. 2016. Start with the Future and Work Back: A Heritage Management Manifesto. Toronto: Rowman \& Littlefield.

White, H. 1973. Metahistory: The Historical Imagination in Nineteenth-century Europe. John Hopkins University Press.

Wineberg, S. 1999. Historical thinking and other unnatural acts. The Phi Delta Kappan, 80(7): 488-499.

Winston, B. 1998. Mediatechnology and Society: A history from the telegraph to the internet. London: Routledge.

Ybema, S. 2014. The invention of transitions: History as a symbolic site for discursive struggles over organizational change. Organization, 21(4), 495-513.

Zerubavel, E. 2003. Time Maps: Collective Memory and the Social Shape of the Past. Chicago, Il: University of Chicago Press. 